\title{
Interactional Justice and Organizational Citizenship Behaviour of Academic Staff in Universities in Bayelsa State
}

\author{
Tarela Oboro Okpu, Gift J. Eke
}

\begin{abstract}
This study was carried out to ascertain the effect of Interactional Justice on Organizational Citizenship Behaviour of Academic Staff in Universities in Bayelsa State. Cross Sectional Research design was adopted. A sample size of 294 was obtained from a population of 1,268 workers, using Krejcie and Morgan (1970) Sample size determination table. With the aid of Statistical Package for Social Sciences, the Spearman Rank Order Correlational Coefficient was used to analyse the data. The results obtained showed a significant positive relationship between Interactional Justice and all measures of Organizational Citizenship Behaviour (Altruism, Courtesy, Conscientiousness, Civic Virtue, and Sportsmanship), indicating that workers are very helpful and assist colleagues with problems. It was recommended that management should always be polite and respectful to employees and involve them in decision making because employees perception of equity breeds extra role behaviour.
\end{abstract}

Index Terms - Interactional Justice, Organizational Citizenship Behaviour, Organizational Justice.

\section{INTRODUCTION}

Organizational Citizenship Behaviour is a topical issue in management discourse. Firms seek employees who are totally committed to their vision to enable the attainment of organizational goals and objectives. This can be achieved when employees have Organizational Citizenship Behaviour (OCB). OCB is a set of discretionary workplace behaviour that goes beyond the requirements of job duties and specification [24]. The importance of OCB has made management practitioners implement the contributions made by researchers on those job and organizational characteristics that improves this behaviour in workers: such as intrinsic and extrinsic job satisfaction [31]; conducive working conditions [36]; leader-member exchange, organizational inflexibility, perceived organizational support and interactional Justice, [5]; organizational justice [23]; Psychological Capital [53]. These contributions notwithstanding, issues still abound on lack of Organizational Citizenship Behaviour in workers.

Ngugi [36] reports low morale and low performance among bankers in his study of Kenya banks, and how this can be ameliorated with $\mathrm{OCB}$, especially when there is conducive working conditions. A lot of firms are still not

Published on July 25, 2020.

Tarela Oboro Okpu, Niger Delta University, Nigeria.

Gift J. Eke, Niger Delta University, Nigeria.

(corresponding e-mail: tarela $21{ }^{@}$ yahoo.com)

(e-mail: giftyeke@yahoo.com). being optimal in their use of resources; efficiency and effectiveness is still a problem and there is a wide cry on how to achieve competitive edge in the industry [41], [48]. These problems necessitated this present research work which examined the effect interactional justice had on organizational citizenship behaviour. There is paucity of research in this area as most related works were carried out in Western and Eastern climes with multiple constructs [23], [5]. The three dimension of Organizational Justice seems to be the most used approach in the Justice Literature [16].

This study however examined interactional justice (a dimension of Organizational Justice) because the interpersonal and informational relationship between workers and their supervisors is highly motivating and can make employees to go beyond expected behaviours in carrying out their job duties [13], [37], [47], [34], [[7]. Researchers [44], [34], [1] believe Interactional Justice is more influential than other Justice dimensions. The framework below is drawn to show the relationship among the variables of the study. The review of literature will be based on this.

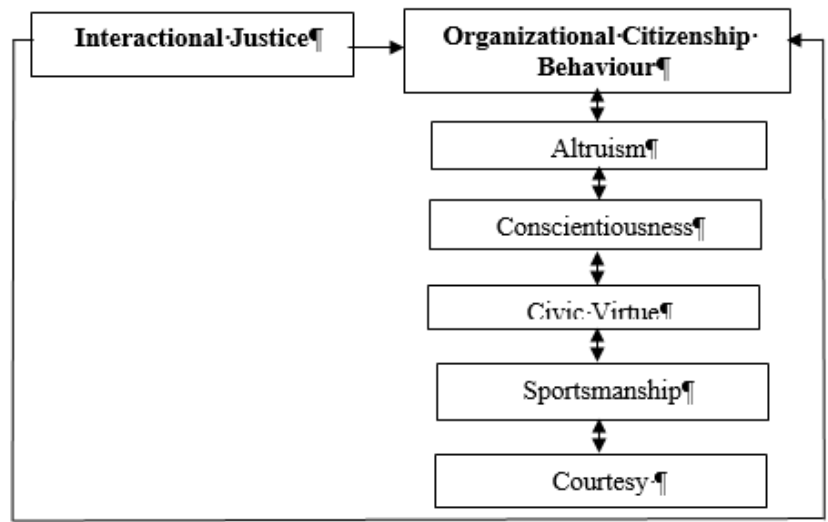

Fig.1. Conceptual framework of interactional justice and organizational citizenship behaviour.

\section{LITERATURE REVIEW}

Equity theory is at the heart of organizational justice. Employees' perception of the fairness of the interpersonal relationship between them and management determines their output in that organization. Equity theory was propounded by Adams [54]. It describes the process employed by workers in maintaining equity between their inputs and the outputs they receive when compared to referent others in the organization. Employees' perception of inequity will make them to either reduce or increase their input in cases of 
perceived under-reward or over-reward, just to ensure justice prevails [3]. Employees' perception of fairness in the informational and interpersonal interaction with their supervisors has a direct and positive effect on Organizational Citizenship Behaviour. Where there is equity, it is natural for employees to go the extra mile for the organization which may contribute to organizational performance [5].

\section{A. Interactional Justice}

Interactional justice according to Bies and Moag [56]) deals with respect, propriety, truthfulness and justification of actions. Supervisors need to respect, be honest and give clear directives to subordinates without being improper or prejudiced. Greenberg [21] collapsed Bies and Moag [56] classification into two: interpersonal justice and informational justice. Scholars have argued that there is really no need for such distinctions, because interactional justice encompasses both interpersonal and informational dimensions [27], [17], [10], [9].

Interactional justice deals with supervisor/subordinate relationship detailing the social aspect of organizational justice [13]. Bies [9] identified the following factors as portraying the absence of interactional justice in organizations: use of abusive and insultive words, deception, invasion of privacy, rudeness, coercion and disclosure of confidence. In their research, Bies and Shapiro [10] studied the influence of causal account on interactional fairness judgements and found that employees view organizations that provide causal explanation for their actions as being fair and just. Jha and Jha [25] reports that workers' perception of being treated equitably by management helps to strengthen their extra discretionary effort.

\section{B. Organizational Citizenship Behaviour}

Organ [41] defines Organizational Citizenship Behaviour (OCB) as an "individual behaviour that is discretionary, not directly or explicitly recognized by the formal reward system, and in the aggregate promotes the efficient and effective functioning of the organization". He sees the workers discretionary action as a voluntary behaviour that goes beyond the call of duty and the requirements of his employment contract, without expectations of rewards but contributing to the effectiveness of the organization.

Organ [43] identified the following as dimensions of OCB:

a) Altruism, "helping other members of the organization in their tasks. This involves being helpful or assisting colleagues, bosses, and other stakeholders of the organization [42]. This involves helping others voluntarily in order to prevent work related problems; being selfless in rendering assistance to people generally in the organization.

b) Courtesy, "preventing problems deriving from the work relationship." This involves being considerate to others in the organization. Ensuring that you clear up after using any equipment or machine in the office. Showing consideration to others in all you do [42].

c) Sportsmanship, "accepting less than ideal circumstances." This involves being tolerant and uncomplaining and having a positive outlook about issues and problems in the firm; sacrificing to ensure the organization moves forward irrespective of any negativism by colleagues [42].

d) Civic virtue, "responsibly participating in the life of the firm." Employees' with this behavioural trait participates actively in all the organization's activities such as attending meetings, selling the organization positively to others, being proactive about the strength, weakness, threats and opportunities facing the organization from its internal and external environment. Such an employee proudly identifies with the organization and willingly accepts responsibilities and expectations such membership entails by abiding to the culture, policies and promoting strategies to assist the organization grow [42].

e) Conscientiousness, "dedication to the job and desire to exceed formal requirements in aspects such as punctuality or conservation of resources." It involves being honest and doing the right thing always even when no one is watching. Adhering strictly to organizations rules, regulations and policies such as punctuality to work, break timing, not engaging in idle gossips while at work, etc. [42].

Williams and Anderson [50] broke down these dimensions of OCB into two broad categories: Organizational Citizenship Behaviour that directly affects the organization (OCBO) and Organizational Citizenship Behaviour that is inherent in the Individual (OCBI). Altruism and Courtesy were seen as OCBI while Civic Virtue, Conscientiousness and Sportsmanship were classified as OCBO [42], [45], [46].

Researchers [49], [35], [29], [22] have shown strong relationship between OCBO and OCBI on job and organizational related factors such as job performance and organizational effectiveness, cognition and affect, organizational commitment, among others.

\section{Interactional Justice and Organizational Citizenship Behaviour (OCB)}

Several studies have highlighted the relationship between Interactional Justice and Organizational Citizenship Behaviour [1], [12], [33], [32], [51], [15], [46], [49], [35], [38], [37], [47], [34], [28], [12] showed how workers are motivated to comply with workplace policies, are conscientious and exhibit altruistic behaviour when they perceive management to be fair and just. Cropanzano [16] found interactional justice very helpful to organizations that introduced pay cuts, because employees felt management carried them along and are truthful and empathetic about the whole process.

In a similar vein [30] reports that when workers perceive management is honest and treats them with respect during retrenchment exercises, it reduced the risk of litigation by the employees. Skarlicki and Latham [45] explained that leaders who were honest, justified their actions to employees and treated them with courtesy and respect were able to elicit positive organizational citizenship behaviour in such workers. Wei [49] investigated the benefits of OCB on job performance of 56 high technology firms in Taiwan. He found that good interpersonal relationship between employees and the organization had a direct influence on the relationship between OCBO and OCBI bringing about improved job performance and organizational effectiveness. This relationship was moderated by employees' human and 
intelligential capital.

Newman [35] in her study reports that OCBO (Civic Virtue, Sportsmanship and Conscientiousness) was more predominant in participants than OCBI (Altruism and Courtesy). Her result was based on data collected from college students enrolled in psychology courses at Southeastern University. This finding may be attributed to students not having team cohesiveness with their fellow students but having great commitment to their institution of learning. They identified more with their school and are willing to go the extra mile for their institution. Lee and Allen [29] in their study of registered nurses in Canada found strong correlation between OCBO and Job Cognition because such behaviours are planned and deliberate; while OCBI was strongly correlated with job affect since it involves emotions.

In a similar vein, Huang and You [22] explained how organizational commitment strongly influenced OCBI and OCBO. Employees who have affective, continuance and normative commitments are more prone to exhibiting extra discretionary efforts in the organization. This relationship is based on the positive interpersonal and informational role management play in the course of their work. Greenberg [21] reiterated that when employees are given explanations about organizations decisions, they perceive they are treated fairly. Researchers [19], [8], [52], [18], [7], [6], [52], [2] have found strong support for the relationship between interactional justice and organizational citizenship behaviour. When employees perceive organizational policies and treatment meted out on them as being fair and just, their OCB increases leading to higher organizational productivity. Interactional justice has been shown to positively affect employees' conscientiousness and civic virtue [52].

Ali [2] in his study of the effect of Organizational Justice on the OCB of doctors in Pakistan public hospitals found that the doctors did not exhibit altruism owing to the way they were treated by their employer (government). Thus, the doctors reduced their output with the perception that there exists inequity in the way they were being treated by government.

From the foregoing, we hypothesized that:

$\mathrm{HO}_{1}$ There is no significant relationship between Interactional Justice and Altruism.

$\mathrm{HO}_{2}$ There is no significant relationship between Interactional Justice and conscientiousness.

$\mathrm{HO}_{3}$ There is no significant relationship between Interactional Justice and Civic Virtue.

$\mathrm{HO}_{4}$ There is no significant relationship between Interactional Justice and Sportsmanship.

$\mathrm{HO}_{5}$ There is no significant relationship between Interactional Justice and Courtesy.

\section{METHOD}

The study adopted cross sectional survey research design. The population was made up of 1,268 academic staff of universities in Bayelsa State. Using Krejcie and Morgan table on sample size determination table, a sample size of 294 respondents were obtained. The retrieved and usable copies of questionnaire were 251, after cleaning and coding; representing $85 \%$ response rate. The instrument used for data collection was a 4 point Likert type of questionnaire, with response category ranging from 4 - strongly agree to 1 - strongly disagree. The variables were measured from existing studies - Interactional Justice Scale was adapted from Colquitt [14] study, while OCB Scale was adapted from Podsakoff et al [59] study. Our studies had content validity as renowned scholars were used to validate it. The variables also had construct validity because they were sourced from existing studies and had been pretested and validated by other works [57]-[61]. Cronbach Alpha was used to test for reliability of our variables. Bryman and Bell [62] stated that an Alpha Coefficient of 0.7 is considered as efficient, hence our variables were all efficient as given by the table below:

TABLE 1. RELIABILITY ANALYSIS SCALE (ALPHA)

\begin{tabular}{|l|l|l|l|}
\hline Variable & $\begin{array}{l}\text { No. of } \\
\text { cases }\end{array}$ & $\begin{array}{l}\text { No. of } \\
\text { items }\end{array}$ & Alpha \\
\hline Interactional Justice & 251 & 9 & 0.804 \\
\hline $\begin{array}{l}\text { Organizational Citizenship } \\
\text { Behaviour }\end{array}$ & 251 & 23 & 0.873 \\
\hline
\end{tabular}

Source: SPSS computation

The Spearman Rank Order Correlational Coefficient was used to test the association between our variables with the use of Statistical Package for Social Scientists (SPSS). The confidence level was set at 0.05 level of significance.

\section{RESUlts}

TABLE 2. CORRELATION BETWEEN INTERACTIONAL JUSTICE AND ALTRUISM

\begin{tabular}{|c|c|c|c|c|}
\hline & & & IJS & AS \\
\hline \multirow{6}{*}{$\begin{array}{c}\text { Spearman's } \\
\text { rho }\end{array}$} & \multirow{3}{*}{ IJS } & Correlation Coefficient & 1.000 & $.622^{* *}$ \\
\hline & & Sig. (2-tailed) &. & .000 \\
\hline & & $\mathrm{N}$ & 251 & 251 \\
\hline & \multirow{3}{*}{ AS } & Correlation Coefficient & $.622^{* *}$ & 1.000 \\
\hline & & Sig. (2-tailed) & .000 &. \\
\hline & & $\mathrm{N}$ & 251 & 251 \\
\hline
\end{tabular}

Source: SPSS computation **.

Correlation is significant at the 0.01 level (2-tailed).

Results reveal a significant relationship between interactional justice and altruism where rho $=0.622$ and $\mathrm{P}=$ 0.000. Evidence indicates that interactional justice significantly contributes towards actions or behaviour that reflect altruism; hence the null hypothesis is rejected.

TABLE 3. CORRELATION BETWEEN INTERACTIONAL JUSTICE AND

\begin{tabular}{|l|l|l|c|c|}
\hline \multicolumn{3}{|c|}{ CONSCIENTIOUSNESS } \\
\hline \multirow{4}{*}{$\begin{array}{l}\text { Spearman's } \\
\text { rho }\end{array}$} & \multirow{3}{*}{ IJS } & Correlation Coefficient & 1.000 & $.291^{* *}$ \\
\cline { 3 - 5 } & & Sig. (2-tailed) &. & .000 \\
\cline { 2 - 5 } & \multirow{3}{*}{$\mathrm{N}$} & 251 & 251 \\
\cline { 2 - 5 } & CSS & Correlation Coefficient & $.291^{* *}$ & 1.000 \\
\cline { 3 - 5 } & & Sig. (2-tailed) & .000 &. \\
\cline { 3 - 5 } & $\mathrm{N}$ & 251 & 251 \\
\hline
\end{tabular}

Source: SPSS computation **. Correlation is significant at the 0.01 level (2-tailed)

Results reveal a significant relationship between interactional justice and conscientiousness where rho $=$ 0.291 and $\mathrm{P}=0.000$. Evidence indicates that interactional justice significantly contributes towards actions or behaviour that reflect conscientiousness; hence the null 
hypothesis is rejected.

TABLE 4. CORRELATION BETWEEN INTERACTIONAL JUSTICE AND CIVIC VIRTUE

\begin{tabular}{|l|l|l|c|c|}
\hline \multicolumn{3}{|c|}{ VIRTUE } & IJS & CVS \\
\hline \multirow{4}{*}{$\begin{array}{l}\text { Spearman's } \\
\text { rho }\end{array}$} & \multirow{3}{*}{ IJS } & Correlation Coefficient & 1.000 & $.229^{* *}$ \\
\cline { 2 - 5 } & & Sig. (2-tailed) &. & .000 \\
\cline { 2 - 5 } & \multirow{2}{*}{\begin{tabular}{l} 
CV \\
\cline { 2 - 5 }
\end{tabular}} & Correlation Coefficient & $.229^{* *}$ & 1.000 \\
\cline { 2 - 5 } & $\mathrm{S}$ & Sig. (2-tailed) & .000 &. \\
\cline { 3 - 5 } & & $\mathrm{N}$ & 251 & 251 \\
\hline
\end{tabular}

Source: SPSS computation $* *$. Correlation is significant at the 0.01 level (2-tailed).

Results reveal a significant relationship between interactional justice and civic virtue where rho $=0.229$ and $\mathrm{P}=0.000$. Evidence indicates that interactional justice significantly contributes towards actions or behaviour that reflect civic virtue; hence the null hypothesis is rejected.

TABLE 5. CORRELATION BETWEEN INTERACTIONAL JUSTICE AND

\begin{tabular}{|c|c|c|c|c|}
\hline \multicolumn{5}{|c|}{ SPORTSMANSHIP } \\
\hline & & & IJS & SMS \\
\hline \multirow{6}{*}{$\begin{array}{l}\text { Spearman's } \\
\text { rho }\end{array}$} & \multirow{3}{*}{ IJS } & Correlation Coefficient & 1.000 & $.253^{* *}$ \\
\hline & & Sig. (2-tailed) & 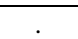 & .000 \\
\hline & & $\mathrm{N}$ & 251 & 251 \\
\hline & \multirow{3}{*}{$\begin{array}{l}\text { SM } \\
\text { S }\end{array}$} & Correlation Coefficient & $.253^{* *}$ & 1.000 \\
\hline & & Sig. (2-tailed) & .000 & . \\
\hline & & $\mathrm{N}$ & 251 & 251 \\
\hline
\end{tabular}

Source: SPSS computation **. Correlation is significant at the 0.01 level (2-tailed).

Results reveal a significant relationship between interactional justice and sportsmanship where rho $=0.253$ and $\mathrm{P}=0.000$. Evidence indicates that interactional justice significantly contributes towards actions or behaviour that reflect sportsmanship; hence the null hypothesis is rejected.

TABLE 6. CORRELATION BETWEEN INTERACTIONAL JUSTICE AND COURTESY

\begin{tabular}{|c|c|c|c|c|}
\hline & & & IJS & AS \\
\hline \multirow{6}{*}{$\begin{array}{c}\text { Spearman's } \\
\text { rho }\end{array}$} & \multirow{3}{*}{ IJS } & Correlation Coefficient & 1.000 & $.226^{* *}$ \\
\hline & & Sig. (2-tailed) & 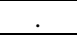 & .000 \\
\hline & & $\mathrm{N}$ & 251 & 251 \\
\hline & \multirow{3}{*}{ AS } & Correlation Coefficient & $.226^{\text {** }}$ & 1.000 \\
\hline & & Sig. (2-tailed) & .000 & . \\
\hline & & $\mathrm{N}$ & 251 & 251 \\
\hline
\end{tabular}

Source: SPSS computation **. Correlation is significant at the 0.01 level (2-tailed).

Results reveal a significant relationship between interactional justice and courtesy where rho $=0.226$ and $\mathrm{P}=$ 0.000. Evidence indicates that interactional justice significantly contributes towards actions or behaviour that reflect courtesy; hence the null hypothesis is rejected.

From the above results the null hypotheses were rejected, and the following relationship are established:

- There is a significant positive relationship between Interactional Justice and Altruism.

- There is a significant positive relationship between Interactional Justice and conscientiousness.

- There is a significant positive relationship between Interactional Justice and Civic Virtue.

- There is a significant positive relationship between Interactional Justice and Sportsmanship.

- There is a significant positive relationship between Interactional Justice and Courtesy.

\section{DISCUSSION}

The findings showed that interactional justice has a significant positive relationship with the dimensions of Organizational Citizenship Behaviour - Altruism, Courtesy, Civic Virtue, Conscientiousness and Sportsmanship. This is similar to the findings of previous studies [1], [12], [33], [32], [51], [15], [45], [49], [35], [37], [47], [34], [38].

The findings are also in support of researches [41], [45], [46], [49], [35], [29], [22] that group OCB into OCBI and OCBO, showing that both individual and organizational aspects of OCB have a positive relationship with Interactional Justice.

Interactional Justice having a significant positive influence on Academic Staff OCB goes further to buttress the fact that when employees participate actively in organizational decision making, it makes them to be fully committed in implementing those decisions and increases their work passion and commitment [39], [40] - which is a precursor of OCB. The University structure whereby decisions are arrived at by board members agreement on all levels of Management - from departmental, faculty, senate, to governing councils - makes the head of these units to show respect and consideration to staff members and disseminate information in a timely and truthful manner which spurs workers to perform above their prescribed job duties.

Interactional Justice significantly influenced workers Altruistic behaviour towards co-workers. Academic staff in universities in Bayelsa State assist their colleagues who have work related problems and heavy workloads. They act as mentors and are very helpful. This finding supports previous researches [28], [19], [6] that when employees perceive that management treats them with respect and dignity and are trustworthy, it brings out their altruistic tendency of helping others and the ability to grow both personally and professionally, thereby increasing the organizational performance with the extra discretionary behaviour displayed by workers. Our findings run contrary to Ali [2] research. In his work Interactional Justice had no significant influence on the altruistic behaviour of respondents. This is not surprising because the doctors in the public hospital of Pakistan had embarked on a series of strike action owing to the inability of government to meet their needs. In line with Adams equity theory, employees will reduce their output if they believe their exist inequity in the organization.

The findings that Interactional justice significantly influenced courtesy of Academic staff in universities in Bayelsa state supports previous studies [2], [52]. Employees are careful with their dealings with others and avoid creating problems. They try not to abuse the rights of co-workers. According to Ali [2] when supervisors are polite and respectful to subordinates, they exhibit courteous behaviour in return. A perception of fairness increases workers positive extra role behaviour.

Interactional justice significantly influences workers Conscientiousness towards co-workers. Academic staff attend school functions and meetings and are given voice regarding decisions taken by board agreements. This 
supports Yardan, et al [52] findings that interactional justice has a positive effect on workers Conscientiousness.

Interactional justice significantly influences workers civic virtue behaviour in the organization. Academic staff are respectful of University rules and policies and put in a lot of effort in their work by working extra hours to meet their research and other academic requirements.

Interactional justice significantly influences workers sportsmanship behaviour in the organization. Academic staff are positive about issues in the university and avoid unnecessary complaints. They rather try to proffer solutions to problems. This finding is contrary to Yardan et al [52] results which reported that there was a negative relationship between interactional Justice and Sportsmanship. This is not surprising because their respondents were medical workers in public hospitals in Turkey and there were reports on how workers perceive that the government was insensitive to their welfare and security. Research has demonstrated that when workers perceive inequity in their organization, they reciprocate by reducing their output to restore equity [55].

Employees react to the presence or absence of equity in the organization by increasing or decreasing their output. In the presence of Interactional Justice, employees are more loyal, committed and go beyond the call of duty without expectations of rewards [41], [6], [33], [63], [64].

\section{CONCLUSION AND RECOMMENDATIONS}

Academic Staff of Universities in Bayelsa State exhibit Organizational Citizenship Behaviour. They are passionate about their work and are very helpful to colleagues. They go the extra mile by ensuring their organization is effective and efficient in producing graduates that can influence the society positively. This helps in human capital development and transcends to intellectual capital development in most firms. These can be achieved because there is a cordial relationship between heads of units and subordinates. Workers are treated in a polite and respectful manner, with information being decimated in a timely and accurate way. Employees have a voice in decision making and this spurs workers in the implementation of organizational policies and rules.

Employees' perception of interactional justice increases their extra role behaviour in universities. When they are provided information about wages, promotion and other organizational policies in a timely, truthful and fair manner by management, it spurs them towards going the extra mile for the university and in turn increases organizational effectiveness and efficiency.

Therefore, there is need for supervisors to improve their information and interpersonal relationship with their staff. This will bring about a more relaxing and pleasing climate in organizations, whereby workers will be motivated to put in their best without expectation of rewards. Thus, employees' perception of being treated fairly in the organization increases OCB [47].

\section{REFERENCES}

[1] Afari, T. S. and Elanain, H. M. A., (2014); Procedural And Distributive Justice As Mediators Of The Relationship Between
Interactional Justice And Work Outcomes: An Empirical Study Of The UAE Public Health Care Sector The Journal of Applied Business Research 30(4)

[2] Ali, N. (2016) effect of organizational justice on OCB: a study of health sector of Pakistan, Review of Public Administration and Management, 4(3), 1-9.

[3] Al-Zawahrey, A. and Al-Madi, F. (2012) the utility of equity theory in enhancing organizational effectiveness, European Journal of Economics, Finance and Administrative Sciences, 46, 158-170.

[4] Argentero, P., Cortese, C. G., \& Ferretti, M. S. (2008). An evaluation of organizational citizenship behavior: Psychometric characteristics of the Italian version of Podsakoff et al.'s scale. TPM-Testing, Psychometrics, Methodology in Applied Psychology, 15(2), 61-75.

[5] Asgari, A., Silong, A.D., Ahmad, A, and Samah, B. A. (2008) the relationship between leader-member exchange, organizational inflexibility, perceived organizational support, interactional justice and Organizational Citizenship Behaviour, African Journal of Business Management, 2(8), 138-145.

[6] Azizolla, A., Hajipour, R., and Mahdi, S. S. (2014) the correlation between justice and $\mathrm{OCB}$ and organizational identity among nurses, Global Journal of Health Sciences 6(6), 252-260.

[7] Badu, C. A., and Asumeng, M. (2013) perceived organizational justice and employees' OCB in Ghana, European Journal of Business and Management 5(19), 144-150.

[8] Bahrami, M. A., Montazeralfaraj, R., Gazar, S. H., and Tafti, A. D. (2014) relationship between organizational perceived justice and OCB among an Iranian Hospital employees, Electron Physician, 6(2), 838844.

[9] Bies, R. J. (2001). Interactional (in)justice: The sacred and the profane. In: J. Greenberg \& R. Cropanzano (Eds), Advances in Organizational Justice (89-118). Stanford, CA: Stanford University Press.

[10] Bies, R.J. and Shapiro, D.L. (1987) Interactional Fairness Judgments: The Influence of Causal Accounts. Social Justice Research, 1, 199218.

[11] Chelagat, L. J., Kiprop, C. P. and Kemboi, A. (2015) effect of OCB on Employee performance in banking sector Nairobi country, Kenya, International Journal of Business, Humanities and Technology, 5(4), 55-61.

[12] Cohen-Charash, Y., \& Spector, P. E. (2001). The role of justice in organizations: A meta-analysis. Organizational Behavior and Human Decision Processes, 86, 278-321.

[13] Çolak, M. \& Erdost, H. E. (2004). Organizational justice: A review of the literature and some suggestions for future research. Hacettepe University, Journal of Faculty of Economics and Administrative Sciences, 22(2), 51-84.

[14] Colquitt, J. A., \& Rodell, J. B. (2015). Measuring justice and fairness. In R. S. Cropanzano \& M. L. Ambrose (Eds.), Oxford library of psychology. The Oxford handbook of justice in the workplace (p. 187-202). Oxford University Press.

[15] Coyle-Shapiro, J., Kessler, J., \& Purcell, J. (2004). Exploring organizationally directed citizenship behaviour: reciprocity or 'It's my Job'? Journal of Management Studies, 41(1), 85-106.

[16] Cropanzano, R., Rupp, D.E., Mohler, C. J., and Schminke, M. (2015) three roads to organizational justice in research, Personnel and Human Resource Management, 20, 1-113.

[17] Deschamps, C., Rinfret, N., Lagace, M.C., \& Prive, C. (2016). Transformational leadership and change: How leaders influence their followers' motivation through organizational justice. Journal of Healthcare Management, 61, 194-213.

[18] Farahbod, F., Azadehdel, M., Rezae-I Dizgah, M. \& Nezhadi-Jirdehi, M. (2012). Organizational citizenship behavior: The role of organizational justice and leader- member exchange, Interdisciplinary Journal of Contemporary Research in Business, 3(9), 893-903.

[19] Farh, J. L., Podsakoff, P.M., \& Organ, D. W. (2000). Accounting for organizational Citizenship behavour: Leader fairness and task scope versus satisfaction. Journal of management, 16, 705721.

[20] Greenberg, J. (1993). Stealing in the name of justice: Informational and interpersonal moderators of theft reactions to underpayment inequity. Organizational Behavior and Human Decision Processes, $54,81-103$

[21] Greenberg, J. (2000), “Organizational Justice: Yesterday, Today, and Tomorrow”, Journal of Management, Vol. 16, pp.399-432.

[22] Huang, C. and You, C. (2011) the three components of organizational commitment on in-role behaviours and organizational citizenship behaviours, African Journal of Business Management 5(28), 1133511344. 
[23] Jafari, P., and Bidarian, S. (2012) the relationship between justice and organizational citizenship behaviour, Procedia Social and Behavioural Sciences, 45, 1815-1820.

[24] Jahangir, N., Akbar, M.M., and Hag, M. (2004) Organizational Citizenship Behaviour: its nature and antecedents, BRAC University Journal, 1(2), 75-85.

[25] Jha, S. and Jha, S. (2010) determinants of organizational citizenship behaviour: a review of literature, Journal of Management and Public Policy, 1(2), 27-36.

[26] Krejcie R.V \& Morgan D.W (1970). Determining Sample Size for Research Activities. Educational and Psychological Measurement 30 , $607-610$.

[27] Krishnan, R., Loon, K. W., Ahmad, N. A. F. binti, \& Yunus, N. A. S (2018). Examining the relationship between organizational justice and job performance. International journal of academic research in business and social sciences, 8(3), 466-477.

[28] Lawrence-Chukwu, E. J., Eketu, C. A. and Needom, R. (2018) organizational justice and workers citizenship behaviour: a study of hotels in Port Harcourt, International Journal of Advanced Academic Research, Social and Managerial Sciences 4(5), 103-128.

[29] Lee, K., \& Allen, N.J. (2002). Organizational citizenship behavior and workplace deviance: the role of affect and cognition. Journal of Applied Psychology, 87, 131-142. Doi: 10.1037//0021-9010.87.1.131.

[30] Lind, E. A., Greenberg, J., Scott, K. S., \& Welchans, T. D. (2000). The winding road from employee to complainant: Situational and psychological determinants of wrongful termination claims. Administrative Science Quarterly, 45, 557-590.

[31] Mohammad, J., Habib, F. Q., and Alias, M. A. (2011) Job satisfaction and organizational citizenship Behaviour: an empirical study of higher learning institutions, Asian Academy of Management Journal 16(2), 149-165.

[32] Moorman, C., Zaltman, G., \& Deshpande, R. (1993). Factors affecting trust in marketing relationships. Journal of Marketing, 57(1) 81-101.

[33] Moorman, R. H. (1991). Relationship between organizational justice and organizational citizenship behaviors: does fairness perception influence employee citizenship? Journal of Applied Psychology, 76(6), 845-855

[34] Muzumdar, P., (2012); Influence of interactional justice on the turnover behavioral decision in an organization, Journal of Behavioral Studies in Business, 4, 1-11.

[35] Newland, S. J., (2012) "Organizational Citizenship Behavior Individual or Organizational Citizenship Behavior- Organization: Does the Underlying Motive Matter?" Masters Theses \& Specialist Projects. Paper 1159. http://digitalcommons.wku.edu/theses/1159.

[36] Ngugi, J. (2017) role of working conditions on OCB in the banking industry: a survey of Barclays Bank in North Rift Region, IOSR Journal of Business and Management, 19(16), 32-37.

[37] Nidhi, D. and Kumari K. (2016) Interactional justice: a key to OCB International Journal of Pure and Applied Management Sciences 1(2), 22-28.

[38] Nwibere, B. M. (2014) organizational justice as a determinant in the Nigerian work environment: a study of selected universities in the Niger Delta Region, International Journal of Business and Management, 9(4), 191-205.

[39] Okpu, T. and Basuo, B. K. (2019) organizational justice and employee work passion in Nigerian Universities, European Journal of Business and Management, 11(14), 45-56.

[40] Okpu, T. and Kpakol, A. G. (2018) enhancing job engagement through employee voice in Nigerian Banking Industry, IOSR Journal of Business and Management 20(1), 24-34.

[41] Organ, D. W. (1988). Issues in organization and management series. Organizational citizenship behavior: The good soldier syndrome. Lexington, MA, England: Lexington Books/D. C.

[42] Organ, D. W. (1997) Organizational Citizenship Behaviour: its construct clean-up time, Human Performance, 10 (2), 85-97.

[43] Organ, D.W. (1988) O.C.B the Good Soldier Syndrome. Lexington Books: Lexington, MA, Podsakoff, P. M., MacKenzie, S. B., Moorman, R. H., \& Fetter, R. 1990. Transformational leader behaviors and their effects on followers' trust in leader, satisfaction, and organizational citizenship behaviors. Leadership Quarterly, 1, $107-142$

[44] Poyraz, K., Kara, H. \& Çetin, S.A. (2009). Örgütsel Adalet Algılamalarının Örgütsel Vatandaşlık Davranışlarına Etkisine Yönelik Bir Araştırma. S.D.Ü. Sosyal Bilimler Enstitüsü Dergisi, 1(9), 71-91.

[45] Skarlicki, D. P., \& Latham, G. P. (1996). Increasing citizenship behavior within a labor union: A test of organizational justice theory. Journal of Applied Psychology, 81, 161-169.
[46] Skarlicki, D.P. and Latham, G.P. (1997) leadership training in organizational justice to increase citizenship behaviour with a labour union: a replication, Personnel Psychology, 50(3), 617-633.

[47] Taamneh, A., (2015); The Impact of Practicing Interactional Justice on Employees Organizational Citizenship Behavior (OCB) in the Jordanian Ministry of Justice, European Journal of Business and Management,7(8), 170-180.

[48] Walz, S. M. \& Niehoff, B. P. (1996) Organizational citizenship behaviors and their effect on organizational effectiveness in limited menu restaurants. Best Paper Proceedings, Academy of Management conference, pp. 307-31.

[49] Wei, Y. (2014) the benefits of organizational citizenship behaviour for job performance and the moderating role of human capital, International Journal of Business and Management 9(7), 87-99.

[50] William, L. J. and Anderson, S. E. (1991) job satisfaction and organizational commitment as predictors of organizational citizenship and in-role behaviour, Journal of Management, 17, 601-617.

[51] Williams, S., Pitre, R., \& Zainuba, M. (2002). Justice an organizational citizenship behaviors intentions: Fair rewards versus fair treatment. Journal of Social Psychology, 142, 33-44.

[52] Yardan, E. D. Kose, D. S. and Kose, T. (2014) the effect of employees' perceptions of organizational justice on OCB: an application in Turkish public hospital, Journal of Human Resources Management and Labour Studies, 2(2), 129-148.

[53] Shahnawaz, M.G. and Jafri, M.H. (2009) Psychological Capital as Predictors of Organizatioanl Commitment and Organizationa Citizenship Behavior. Journal of the Indian Academiy of Applied Psychology, 35, 78-84.

[54] Adams, J. S. (1963) Toward an understanding of inequity. Journal of Abnormal and Social Psychology, 67, 422-436.

[55] Adams, J. S. (1965) Inequity in social exchange. In L. Berkowitz (Ed.), Advances in experimental social psychology (Vol. 2, pp. 267 299). New York: Academic Press.

[56] Bies, R.J. and Moag, J.F. (1986) Interactional Justice: Communication Criteria of Fairness. In: Lewicki, R.J., Sheppard B.H. and Bazerman, M.H., Eds., Research on Negotiations in Organizations, Vol. 1, JAI Press, Greenwich, 43-55.

[57] Podsakoff, P. M., Ahearne, M., \& MacKenzie, S. B. (1997). Organizational citizenship behavior and the quantity and quality of work group performance. Journal of Applied Psychology, 82, 262270.

[58] Podsakoff, P. M., MacKenzie, S. B., Paine, J. B., \& Bachrach, D. G. (2000). Organizational citizenship behaviors: A critical review of the theoretical and empirical literature and suggestions for future research. Journal of Management, 26, 513-563.

[59] Podsakoff, P. M., MacKenzie, S. B., Moorman, R. H., \& Fetter, R. (1990). Transformational leader behaviors and their effects on followers' trust in leader, satisfaction, and organizational citizenship behaviors. Leadership Quarterly, 1, 107-142.

[60] Colquitt, J. A. (2001). On the dimensionality of organizational justice: A construct validation of a measure. Journal of Applied Psychology, $86,386-400$.

[61] Colquitt, J. A., and Shaw, J. C. (2005). How should organizational justice be measured? In J. Greenberg \& J. A. Colquitt (Eds.), Handbook of organizational justice (p. 113-152). Lawrence Erlbaum Associates Publishers.

[62] Bryman, A. and Bell, E. (2003) Business Research Methods. Oxford University Press, Oxford.

[63] Netemeyer R.G., Boles, J.S., McKee, D.O. and McMurrian, R. (1997). An Investigation into the Antecedents of Organizational Citizenship Behaviors in a Personal Selling Context, Journal of Marketing, 61, 85-98.

[64] Konovsky, M. A., \& Organ, D. W. (1996). Dispositional and contextual determinants of organizational citizenship behavior Journal of Organizational Behavior, 17, 253-266. 